\title{
Spotted Knapweed Utilization by Sequential Cattle and Sheep Grazing
}

\author{
Stacee L. Henderson, ${ }^{1}$ Tracy K. Mosley, ${ }^{2}$ Jeffrey C. Mosley, ${ }^{3}$ and Rodney W. Kott ${ }^{3}$ \\ Authors are ${ }^{1}$ Research Assistant, Center for Integrated Pest Management, North Carolina State University, Raleigh, NC 27606, USA; ${ }^{2}$ Agriculture \\ Extension Agent, Montana State University Extension, Livingston, MT 59047, USA; and ${ }^{3}$ Professor, Department of Animal and Range Sciences, Montana \\ State University, Bozeman, MT 59717, USA.
}

\begin{abstract}
Prescribed (or targeted) sheep grazing can effectively suppress the invasive perennial forb spotted knapweed (Centaurea stoebe L. ssp. micranthos [Gugler] Hayek). Some ranchers and other natural resource managers, however, resist using this weed management tool over concerns that sheep may consume too much of the graminoid standing crop, thereby decreasing its availability to cattle and wildlife and possibly harming graminoids with excessive defoliation. One potential approach to address these concerns is to graze spotted knapweed infestations first with cattle, immediately followed by sheep. We evaluated this sequential grazing strategy on foothill rangeland in western Montana, comparing sequential grazing at a moderate stocking rate in mid June (spotted knapweed in bolting stage) vs. mid July (spotted knapweed in late-bud/early flowering stage). Pastures ( 0.81 ha) were grazed with three yearling cattle for $7 \mathrm{~d}$, immediately followed with $7 \mathrm{~d}$ of grazing by seven yearling sheep. Combined relative (i.e., utilization) of graminoids by cattle and sheep averaged $40 \%$ in June and July, safely within sustainable grazing use levels recommended for the site. Combined relative use of spotted knapweed by cattle and sheep also did not differ between June and July, averaging $62 \%$. Previous research indicates that this degree of use is sufficient to suppress spotted knapweed. Our results indicate that prescribed sheep grazing can be applied immediately following cattle grazing in either June or July to suppress spotted knapweed without overusing desirable graminoids. Cattle and sheep will eat less graminoids and more spotted knapweed if cattle and sheep graze sequentially when spotted knapweed is in its late-bud/early flowering stage (mid July) rather than its bolting stage (mid June).
\end{abstract}

\section{Resumen}

El pastoreo prescrito con ovejas puede suprimir de manera efectiva la herbácea perene invasiva spotted knapweed (Centaurea stoebe L. ssp. micranthos [Gugler] Hayek). Sin embargo, algunos ganaderos y manejadores de recursos naturales, se resisten a utilizar esta herramienta de manejo por la preocupación de que las ovejas puedan consumir grandes cantidades de gramíneas, resultando en disminución y disponibilidad para el ganado y fauna silvestre. Asimismo, se teme que el consumo ocasione un daño a las gramíneas por una utilización intensiva. Un posible enfoque para hacer frente a estas preocupaciones es pastorear las áreas infestadas de spotted knapweed primero con ganado vacuno e inmediatamente después con ovejas. Evaluamos esta estrategia de pastoreo secuencial en los pastizales al pie de los lomeríos en el oeste de Montana, comparando el pastoreo secuencial con una densidad animal moderada a mediados de junio (etapa previa a la floración) en comparación con el pastoreo durante mediados de Julio (finales de la brotación/ principios de la época de floración). Parcelas de (0.86 has) fueron pastoreadas con tres vacas de un año por 7 días, inmediatamente fueron pastoreadas por 7 días con siete ovejas de un año. Combinando la utilización relativa de gramíneas por ganado y ovejas promediaron $40 \%$ in Junio y Julio, con seguridad estos niveles de pastoreo son sostenibles recomendados para este sitio. La relativa combinación de la utilización de spotted knapweed por ganado y ovejas tampoco produjo diferencias entre Junio y Julio, promediando $62 \%$. Investigaciones previas indican que este grado de utilización es suficiente para suprimir spotted knapweed. Nuestros resultados indican que el pastoreo prescrito con ovejas puede ser implementado inmediatamente después del pastoreo con ganado vacuno ya sea en Junio o Julio para suprimir spotted knapweed sin la sobrevso de las gramíneas deseables. El ganado vacuno y las ovejas van a consumir menos gramíneas y mas spotted knapweed si ambos pastorean secuencialmente cuando spotted knapweed está en finales de la brotación/ principios de la época de floración (mediados de julio) en lugar de la etapa de floración (mediados de Junio).

Key Words: Centaurea maculosa, Centaurea stoebe, grasses, prescribed grazing, targeted grazing, timing, weeds

\section{INTRODUCTION}

Spotted knapweed (Centaurea stoebe L. ssp. micranthos [Gugler] Hayek) is a nonindigenous, perennial forb that infests

Research was funded by the USDA Joe Skeen Institute for Rangeland Restoration. At the time of research, Henderson was Graduate Research Assistant, Dept of Animal and Range Sciences, Montana State University, Bozeman, MT 59717, USA.

Correspondence: Dr Tracy Mosley, Park County Extension, 414 E Callender, Livingston, MT 59047, USA. Email: tmosley@montana.edu

Manuscript received 23 December 2009; manuscript accepted 23 December 2011. millions of hectares of rangeland in the United States and Canada (Sheley et al. 1999; Duncan 2005). This invasive plant continues to spread at a rate of $10-27 \%$ annually (Griffith and Lacey 1991; Duncan 2005; Montana Weed Summit Steering Committee 2005). Spotted knapweed infestations reduce cattle and wildlife forage (Watson and Renney 1974), reduce biodiversity (Tyser and Key 1988), and inflict dramatic economic damage (Bucher 1984; Hirsch and Leitch 1996).

Prescribed (or targeted) sheep grazing can effectively suppress spotted knapweed (Olson et al. 1997; Launchbaugh 
and Hendrickson 2001). Some ranchers and other natural resource managers, however, resist using this weed management tool over concerns that sheep may consume too much of the graminoid standing crop, thereby decreasing the amount of graminoid forage available to cattle and wildlife and potentially harming graminoids with excessive defoliation. For example, one study from western Montana reported that when sheep prescriptively grazed a light infestation of spotted knapweed (spotted knapweed $=13 \%$ vegetative composition) in its latebud/early flowering stage, graminoids comprised $55 \%$ of sheep diets (Thrift et al. 2008). One potential approach to decrease graminoid consumption by sheep is to graze spotted knapweed infestations first with cattle, immediately followed by sheep (Thrift et al. 2008). Given that cattle on foothill rangeland typically select grass-dominated summer diets (Miller and Krueger 1976; McLean and Willms 1977; Torstenson et al. 2006), cattle grazing immediately before sheep grazing may reduce graminoid availability and increase the relative abundance or palatability of spotted knapweed to the sheep, potentially causing the sheep to eat less graminoids and more spotted knapweed. This strategy potentially mirrors the way that sheep grazing can be followed with cattle grazing to reduce cattle consumption of larkspur (Delphinium L. spp.), a plant that is highly poisonous to cattle but much less toxic to sheep (Alexander 1989; Ralphs et al. 1991; Ralphs and Olsen 1992).

Previous research has determined that prescribed sheep grazing can be effectively applied when spotted knapweed is in either the bolting stage or the late-bud/early flowering stage (Olson et al. 1997; Launchbaugh and Hendrickson 2001; Thrift et al. 2008; Benzel et al. 2009; Surber et al. 2011). The purpose of our study was to investigate whether sequential grazing of cattle and sheep (i.e., grazing first with cattle, immediately followed by sheep) would be better applied when spotted knapweed was in the bolting stage (mid June) or latebud/early flowering stage (mid July). We investigated the effects of the timing of grazing on cattle and sheep diets, forage use (i.e., utilization), and livestock foraging behavior. We hypothesized that sheep would eat less graminoids and more spotted knapweed in July when graminoids were more phenologically advanced and less palatable.

\section{MATERIALS AND METHODS}

\section{Study Area}

The study was located on foothill rangeland in western Montana near Greenough, Montana (lat 46 $54^{\prime} 10.0794^{\prime \prime} \mathrm{N}$, long $\left.113^{\circ} 25^{\prime} 22.8^{\prime \prime} \mathrm{W}\right)$ at an elevation of about $1100 \mathrm{~m}$. The ecological site is Silty, in the $381-\mathrm{mm}$ to $483-\mathrm{mm}$ precipitation zone (USDA-NRCS 2003), and the habitat type is mountain big sagebrush/rough fescue (Artemisia tridentata Nutt. ssp. vaseyana [Rydb.] Beetle/Festuca campestris Rydb.; Mueggler and Stewart 1980). Soils are very deep, somewhat excessively drained, Perma gravelly, and stony loams (Loamy-skeletal, mixed Typic Haploborolls) that formed in alluvium (USDANRCS 2003). The study was conducted within a light infestation of spotted knapweed in which spotted knapweed comprised $18 \%$ of the vegetative composition, as quantified immediately before the initial grazing treatments in June 2006 (see "Data Collection" methods below).
Dominant graminoid species included rough fescue, Idaho fescue (Festuca idahoensis Elmer), bluebunch wheatgrass (Pseudoroegneria spicata [Pursh] Á. Löve), threadleaf sedge (Carex filifolia Nutt.), prairie junegrass (Koeleria macrantha [Ledeb.] Schultes), and Sandberg bluegrass (Poa secunda J. Presl). Dominant forbs were spotted knapweed, silky lupine (Lupinus sericeus Pursh), rose pussytoes (Antennaria rosea Greene), and common yarrow (Achillea millefolium L.). The primary shrub on the site was mountain big sagebrush.

\section{Treatments}

We compared sequential cattle and sheep grazing in mid June vs. mid July in 2 yr (2006 and 2007). During the June grazing treatment, perennial grasses were at the five-leaf to six-leaf stage, and spotted knapweed plants were bolting. Perennial grasses were in the soft dough stage and spotted knapweed was in the late-bud/early flowering stage during the July grazing treatment. Each month and year, three 0.81-ha pastures were grazed with three yearling Angus cattle (bulls, steers, or heifers) for $7 \mathrm{~d}$, immediately followed with $7 \mathrm{~d}$ of grazing by seven yearling Rambouillet wethers. Yearling cattle weights averaged $329 \mathrm{~kg} \cdot$ animal $^{-1}$ and yearling wethers averaged $68 \mathrm{~kg} \cdot \mathrm{ani}^{-}$ $\mathrm{mal}^{-1}$. Stocking rate was 0.6 animal unit month $(\mathrm{AUM}) \cdot \mathrm{ha}^{-1}$ for cattle and $0.3 \mathrm{AUM} \cdot \mathrm{ha}^{-1}$ for sheep, totaling a combined moderate stocking rate of $0.9 \mathrm{AUM} \cdot \mathrm{ha}^{-1}$. Each month and year, all animals were randomly assigned to the pastures following 5-d acclimation grazing periods in adjacent nontreatment pastures to familiarize the livestock with the forage on the study area.

\section{Data Collection and Laboratory Analyses}

Relative use (Frost et al. 1994) of spotted knapweed and perennial graminoids was measured after cattle (relative use by cattle) and sheep (relative use by cattle + sheep) grazing in June and July using the Grazed Class Method (Schmutz et al. 1963; US Department of Agriculture-US Department of the Interior 1996; McKinney 1997). Percentage of use of the nearest perennial graminoid (basal width $\geq 3 \mathrm{~cm}$ ) and spotted knapweed plant was measured at 2-m intervals along a $60-\mathrm{m}$ permanent transect located near the center of each pasture ( $n=30$ spotted knapweed plants $\cdot$ pasture $^{-1}$ and $n=30$ graminoid plants $\cdot$ pasture $^{-1}$ ).

Botanical composition of sheep and cattle diets was determined using microhistological analysis of fecal samples (Sparks and Malechek 1968). In each pasture, fresh fecal samples were collected from cattle and sheep on days 5, 6, and 7 of their respective grazing periods. Waiting to collect feces until day 5 allowed forage ingested during the acclimation grazing periods to clear the digestive tracts of the cattle and sheep (Freeman et al. 1992; Park et al. 1994). Fecal samples were composited for each grazing period $(n=1$ composite sample $\cdot$ species $^{-1} \cdot$ pasture $\left.^{-1}\right)$. Microhistological slides were prepared as described by Davitt and Nelson (1980). Six slides were analyzed per sample, and 25 microscope fields were randomly selected and viewed per slide $\left(n=150\right.$ views $\cdot$ sample $\left.^{-1}\right)$. Slides were analyzed at $\times 100$ magnification; however, $\times 200$ magnifications were used for better resolution of fragments that were difficult to identify (Holechek and Valdez 1985). Plant epidermises were identified by life form (i.e., graminoids, 
forbs, shrubs), with the exception of spotted knapweed, which was identified by species. The presence of all identifiable epidermises in each view was recorded. The frequency addition method (Holechek and Gross 1982b) was used to calculate diet composition.

Correction factors are recommended to improve the accuracy of microhistological analysis whenever the ingested plants vary widely in digestibility (Dearden et al. 1975; Vavra and Holechek 1980; Holechek et al. 1982a; Leslie et al. 1983). Accordingly, we prepared herbage mixtures of graminoids, spotted knapweed, and other forbs following the procedure of Vavra and Holechek (1980). Mixtures were digested for 48 hours using the ANKOM Daisy II incubator (ANKOM Technology, Fairport, NY) using rumen fluid from cows fed a grass/alfalfa (Medicago sativa L.) hay diet. Botanical composition of digested samples was analyzed via microhistological analysis using the same procedures as described above for fecal samples. Correction factors were calculated following the procedure of Leslie et al. (1983). Correction factors were applied to the botanical composition estimates derived from the microhistological analysis of fecal samples to arrive at the final estimates of the botanical composition of cattle and sheep diets.

Vegetative canopy cover was sampled in each pasture immediately before cattle grazing and immediately postcattle/ presheep grazing using a modified Daubenmire Canopy Coverage Method (Daubenmire 1959; Bailey and Poulton 1968). Percentage of canopy cover for all graminoids, forbs, and shrubs was sampled within $20 \times 50 \mathrm{~cm}$ quadrats spaced at $2-\mathrm{m}$ intervals along a permanent $60-\mathrm{m}$ transect located near the center of each pasture $\left(n=30\right.$ quadrats $\cdot$ pasture $\left.{ }^{-1}\right)$. Plant species composition of each pasture was determined by dividing the percentage of canopy cover of each plant species by the summed canopy cover of all plant species within each pasture.

Relative preference indices (RPI) were used to evaluate diet selection by cattle and sheep during each grazing period (Krueger 1972). Preference or avoidance of available forage species was determined by dividing each species' percentage of composition in diets of cattle and sheep (determined via microhistological analyses) by its percentage of composition in the corresponding pasture (determined via canopy cover sampling).

Cattle and sheep foraging behavior was evaluated in June and July by recording the length of time an individual animal spent at a feeding station (i.e., feeding station interval; Ruyle and Dwyer 1985 ) and counting the number of steps taken between feeding stations (El Aich et. al. 1989). A feeding station is the area accessible to a grazing animal without moving its forefeet (Goddard 1968). We observed animals near dawn, during peak foraging, on days 2-7 of the grazing periods. Within each pasture, the three cattle and three randomly selected focal sheep were selected and observed for five minutes each. Focal sheep were selected each morning by observing whichever sheep moved first. We documented animal behavior (i.e., feeding station interval and steps between feeding stations) using a tape recorder in the field and later transcribed the data in the laboratory using an electronic stopwatch.

\section{Statistical Analyses}

The 0.81-ha pastures were the experimental units to which sequential cattle and sheep grazing was applied. Treatments
Table 1. Relative use of graminoids and spotted knapweed ( \pm SE) by cattle, or cattle + sheep, in June or July on spotted knapweed-infested foothill rangeland in western Montana.

\begin{tabular}{lcc}
\hline & \multicolumn{2}{c}{ Month } \\
\cline { 2 - 3 } & June & July \\
\hline & & \\
Cattle & $19(3.9) \mathrm{a}$ & $29(2.3) \mathrm{b}^{1}$ \\
$\quad$ Graminoids & $43(3.3) \mathrm{a}$ & $39(3.5) \mathrm{b}$ \\
$\quad$ Spotted knapweed & & \\
Cattle+sheep & $39(3.3) \mathrm{a}$ & $41(2.4) \mathrm{a}$ \\
Graminoids & $62(3.6) \mathrm{a}$ & $61(1.7) \mathrm{a}$ \\
$\quad$ Spotted knapweed &
\end{tabular}

${ }^{1}$ Means in the same row with the same letter are not different $(P>0.05)$.

were randomly assigned to pastures, with three pastures (i.e., replicates) per treatment. Experimental design was a split-plot in time, with sequential grazing applied in 2 different mo (June and July) in 2 yr (2006 and 2007). The whole-plot factor was month, and the subplot factor was year. Data were analyzed with analysis of covariance using the Generalized Linear Model of SAS software (Version 9.1, SAS Institute, Cary, NC). The pregrazing percentage of canopy cover of spotted knapweed in each pasture was used as the covariable. We examined the main effects of month and year and their interaction on relative herbage use, botanical composition of diets, and livestock foraging behavior.

Forage preferences were evaluated for significance with confidence intervals calculated per Hobbs and Bowden (1982) at $\alpha=0.05$. When confidence intervals did not include 1.0, $\mathrm{RPI}>1.0$ indicated preference, whereas $\mathrm{RPI}<1.0$ indicated avoidance.

All differences were considered significant at $P \leq 0.05$. Percentage data were arcsine square root transformed before statistical analysis to stabilize variances and better approximate normal distributions of residuals (Kuehl 2000). Means and standard errors presented in the text and tables are from untransformed data.

\section{RESULTS}

Graminoid use by cattle was light in both months, but less in June than it was in July (19\% vs. 29\%, respectively; Table 1). Combined graminoid use by cattle and sheep averaged $40 \%$ between June and July. Spotted knapweed use by cattle was slightly greater in June than it was in July (43\% vs. 39\%, respectively), whereas combined spotted knapweed use by cattle and sheep averaged $62 \%$ between June and July.

Timing of grazing had similar effects on the diets of both cattle and sheep (Table 2). Cattle and sheep diets each contained more graminoids in June than they did in July, and cattle and sheep diets both contained more spotted knapweed in July than they had in June. The proportion of other forbs (i.e., total forbs minus spotted knapweed) averaged $42 \%$ between June and July in cattle diets and $46 \%$ in sheep diets. Neither sheep nor cattle ate any shrubs during the study. 
Table 2. Botanical composition ( $\pm \mathrm{SE}$ ) of cattle and sheep diets in June or July on spotted knapweed-infested foothill rangeland in western Montana.

\begin{tabular}{lcc}
\hline & \multicolumn{2}{c}{ Month } \\
\cline { 2 - 3 } & \multicolumn{1}{c}{ June } \\
\hline & & \\
Cattle & & \\
Graminoids & $44(3.1) \mathrm{a}$ & $34(1.6) \mathrm{b}^{1}$ \\
Spotted knapweed & $12(2.3) \mathrm{a}$ & $26(2.8) \mathrm{b}$ \\
Other forbs & $44(1.7) \mathrm{a}$ & $41(1.6) \mathrm{a}$ \\
Sheep & & \\
Graminoids & $39(1.6) \mathrm{a}$ & $31(2.2) \mathrm{b}$ \\
Spotted knapweed & $11(2.1) \mathrm{a}$ & $28(4.7) \mathrm{b}$ \\
$\quad$ Other forbs & $50(1.1) \mathrm{a}$ & $41(2.6) \mathrm{a}$ \\
\hline${ }^{1}$ Means in the same row with the same letter are not different $(P>0.05)$.
\end{tabular}

${ }^{1}$ Means in the same row with the same letter are not different $(P>0.05)$.

Cattle and sheep displayed similar forage preferences and avoidances (Table 3). Cattle and sheep strongly preferred spotted knapweed in July and avoided graminoids in June and July. Other forbs were preferred by both cattle and sheep in June and July.

Livestock foraging behavior was relatively unaffected by whether sequential grazing occurred in June or July, indicating that cattle and sheep perceived their forage similarly in both months (Table 4). In June and July, feeding station intervals averaged $16 \mathrm{~s}$ for cattle and $12 \mathrm{~s}$ for sheep. Cattle took slightly more steps between feeding stations in June than they did in July (2.2 steps vs. 1.9 steps), whereas sheep in June and July averaged 3.2 steps between feeding stations.

\section{DISCUSSION}

Relative use of spotted knapweed averaged $62 \%$ when cattle and sheep grazed sequentially in mid June (spotted knapweed in bolting stage) or mid July (spotted knapweed in late-bud/ early flowering stage). The combined $62 \%$ use of spotted knapweed in our study was achieved while maintaining $40 \%$ graminoid use, well within sustainable grazing use levels (40$60 \%$ ) recommended for foothill rangelands in western Montana (Lacey and Volk 1993; Lee-Campbell 1999).

The combined $62 \%$ use of spotted knapweed in our study was sufficient to suppress the reproduction of this noxious weed. Benzel et al. (2009) reported that $35-40 \%$ relative use during its bolting stage decreased spotted knapweed's viable seed production nearly $90 \%$, and complete removal of its buds and flowerheads during the late-bud/early flowering stage reduced current year's spotted knapweed viable seed production nearly $100 \%$. We observed in our study that sequential cattle and sheep grazing during the late bud/early flowering stage of spotted knapweed removed nearly $100 \%$ of its buds and flowerheads. Olson and Wallander (2001) also reported that sheep readily consumed spotted knapweed buds and flowerheads during its late-bud/early flowering stage.

Cattle and sheep in our study preferred spotted knapweed in July, and cattle and sheep both ate more spotted knapweed and less graminoids in July than they did in June. We attribute this
Table 3. Relative preference indices (RPIs) with confidence intervals (CI) for cattle and sheep grazing in June or July on spotted knapweedinfested foothill rangeland in western Montana.

\begin{tabular}{|c|c|c|c|c|c|}
\hline \multirow[b]{2}{*}{ Species } & \multirow[b]{2}{*}{ Forage class } & \multicolumn{2}{|c|}{ June } & \multicolumn{2}{|c|}{ July } \\
\hline & & $\mathrm{RPI}$ & $95 \% \mathrm{Cl}$ & $\mathrm{RPI}$ & $95 \% \mathrm{Cl}$ \\
\hline \multirow[t]{3}{*}{ Cattle } & Graminoids & 0.80 & $0.62-0.98^{*}$ & 0.67 & $0.58-0.76^{*}$ \\
\hline & Spotted knapweed & 0.72 & $0.34-1.10$ & 2.07 & $1.36-2.78^{*}$ \\
\hline & Other forbs & 2.32 & $1.37-3.27^{\star}$ & 1.28 & $1.12-1.44^{*}$ \\
\hline \multirow[t]{3}{*}{ Sheep } & Graminoids & 0.77 & $0.60-0.94^{*}$ & 0.57 & $0.45-0.68^{*}$ \\
\hline & Spotted knapweed & 0.67 & $0.29-1.05$ & 3.23 & $1.87-4.59^{*}$ \\
\hline & Other forbs & 1.95 & $1.13-2.77^{\star}$ & 1.33 & $1.10-1.56^{*}$ \\
\hline
\end{tabular}

${ }^{*}$ When confidence intervals do not include 1.0, RPI $>1.0$ indicates preference, whereas $\mathrm{RPI}<1.0$ indicates avoidance $(\alpha=0.05)$.

response to the graminoids in July being more phenologically advanced and less green and palatable than the spotted knapweed. Similar trends in sheep diets were observed in moderate spotted knapweed infestations (spotted knapweed $=36 \%$ vegetative composition) in western Montana (Thrift et al. 2008; Surber et al. 2011). However, Thrift et al. (2008) reported that when prescribed sheep grazing was applied without cattle in a light spotted knapweed infestation (spotted knapweed $=13 \%$ vegetative composition) similar to our study site ( spotted knapweed $=18 \%$ vegetative composition), sheep ate more graminoids in July than they did in June. Apparently, pregrazing by cattle caused sheep in our study to eat relatively more spotted knapweed in July than they would have consumed had they not grazed immediately after cattle.

Spotted knapweed use in our study $(62 \%)$ was much higher than when prescribed sheep grazing was applied without cattle within spotted knapweed infestations in western Montana (35$50 \%$; Thrift et al. 2008). We attribute the increased use largely to the cattle in our study eating notable amounts of spotted knapweed in both June and July (12\% and $26 \%$ of cattle diets in June and July, respectively). In fact, the levels of relative spotted knapweed use by cattle in our study (i.e., $43 \%$ in June and $39 \%$ in July) approximated the $35-50 \%$ relative use achieved with prescribed sheep grazing alone by Thrift et al. (2008). Casual observations of cattle having eaten spotted knapweed are common (e.g., Robbins 1990; Sheley et al. 1999), but we believe our data are the first in the research literature to quantify spotted knapweed in cattle diets.

Table 4. Feeding station interval and number of steps between feeding stations ( \pm SE) of cattle and sheep grazing in June or July on spotted knapweed-infested foothill rangeland in western Montana.

\begin{tabular}{|c|c|c|}
\hline & \multicolumn{2}{|c|}{ Month } \\
\hline & June & July \\
\hline \multicolumn{3}{|l|}{ Feeding station interval } \\
\hline Cattle & $14.9(0.8) \mathrm{a}$ & $16.7(0.7) a^{1}$ \\
\hline Sheep & $11.0(0.5) \mathrm{a}$ & $12.8(0.5) \mathrm{a}$ \\
\hline \multicolumn{3}{|l|}{$\begin{array}{l}\text { Steps between feeding } \\
\text { stations }\end{array}$} \\
\hline Cattle & $2.2(0.2) \mathrm{a}$ & $1.9(0.1) b$ \\
\hline Sheep & $3.7(0.2) \mathrm{a}$ & $2.7(0.1) a$ \\
\hline
\end{tabular}

${ }^{1}$ Means in the same row with the same letter are not different $(P>0.05)$. 
We were surprised by the extent that cattle consumed spotted knapweed in our study, and we attribute the higher than expected amounts to age, previous experience, and stock density of the cattle. Younger animals typically select more diverse diets than mature animals; grazing animals often select plant species with which they are familiar, and high stock densities encourage grazing animals to forage more uniformly (Arnold and Dudzinski 1978). In our study, the yearling cattle were born and raised on the ranch where our study site was located. Our study animals grazed, at least part of each year, on spotted knapweed-infested foothill rangeland near mature cows with years of previous exposure to this weed. Also, cattle density during our 7 -day grazing periods ( 3.7 yearlings $\cdot \mathrm{ha}^{-1}$ ) was much higher than commonly applied by rangeland cattle producers, although our cattle stocking rate was light (2.2 ha $\left.\cdot \mathrm{AUM}^{-1}\right)$. For comparison, if the same light cattle stocking rate used in our study was applied with mature cows in either $45-\mathrm{d}$ or $60-\mathrm{d}$ grazing periods (i.e., common grazing period lengths for rangeland cattle pastures in the region), cattle density would be about 0.3 or 0.2 cows $\cdot \mathrm{ha}^{-1}$, respectively. If a moderate cattle stocking rate $\left(1.1 \mathrm{ha} \cdot \mathrm{AUM}^{-1}\right)$ was applied with cows in either $45-\mathrm{d}$ or 60 -d grazing periods, cattle density would be 0.6 or 0.4 cows $\cdot \mathrm{ha}^{-1}$, respectively. Therefore, cattle densities in our study ranged from 6.2 to 18.5 times higher than rangeland cattle densities common to the region.

Prescribed cattle grazing at high stock density has been used to effectively suppress Canada thistle (Cirsium arvense [L.] Scop.), an invasive weed in the same taxonomic family (Asteraceae) as spotted knapweed (De Bruijn and Bork 2006). In central Alberta, Canada, De Bruijn and Bork (2006) applied stock densities of 16 to 39 cattle $\cdot \mathrm{ha}^{-1}$ during 3 -d to $4-\mathrm{d}$ grazing periods. These stock densities were much higher than the 3.7 cattle $\cdot \mathrm{ha}^{-1}$ used in our study.

\section{MANAGEMENT IMPLICATIONS}

Prescribed (or targeted) sheep grazing can be effectively applied immediately following cattle grazing when spotted knapweed is either bolting or in its late-bud/early flowering stage. Sequential cattle and sheep grazing at a moderate stocking rate during these phenological stages can suppress spotted knapweed without overusing desirable graminoids. Cattle and sheep likely will both eat more spotted knapweed and less graminoids when sequential cattle and sheep grazing is applied when spotted knapweed is in its late-bud/early flowering stage vs. its bolting stage. Our results also indicate that future research is warranted to refine prescribed cattle grazing strategies for suppressing spotted knapweed. In our study, cattle grazing at a light stocking rate $\left(2.2 \mathrm{ha} \cdot \mathrm{AUM}^{-1}\right)$ and moderately high stock density ( 3.7 yearlings $\cdot \mathrm{ha}^{-1}$ ) during 7 -d grazing periods used spotted knapweed sufficiently to suppress this weed. In much of western North America, where spotted knapweed infestations proliferate, cattle are much more numerous than domestic sheep. Many more hectares of spotted knapweed-infested rangeland might be treatable with targeted livestock grazing if cattle grazing strategies could be refined to suppress spotted knapweed. It is noteworthy that the moderate cattle use of spotted knapweed (39-43\%) and the light cattle use of graminoids (19-29\%) in our study were achieved by cattle grazing at a light stocking rate. Presumably, cattle grazing alone at a moderate stocking rate, with equivalent or higher stock densities, might well increase cattle use of spotted knapweed while keeping graminoid use within moderate, sustainable levels (i.e., $40-60 \%$ use).

\section{ACKNOWLEDGMENTS}

Authors thank Leigh Wiley and Kyle Kelley of Paws Up Ranch for providing access to the study site, cattle, and other logistical support. Authors also gratefully acknowledge Brent Roeder, Rachel Frost, Josh Bilbao, Katie Iverson (Benzel), Stephanie Keep, Cindy Selensky, Merrita Fraker-Marble, and Jenna Mosley for field assistance, and Jim Berardinelli, Lisa Surber, Liz Meyn, and Alison Todd for help with laboratory analyses.

\section{LITERATURE CITED}

AleXANDER, J. D., III. 1989. Sheep grazing as a poisoning control method on tall larkspur populated cattle range [thesis]. Bozeman, MT, USA: Montana State University. $65 \mathrm{p}$.

Arnold, G. W., And M. L. Dudzinski. 1978. Ethology of free-ranging domestic animals. New York, NY, USA: Elsevier Scientific Publishing Co. 198 p.

Balley, A. W., and C. E. Poulton. 1968. Plant communities and environmental relationships in a portion of the Tillamook burn, northwestern Oregon. Ecology 49:1-13.

Benzel, K. R., T. K. Mosley, and J. C. Mosley. 2009. Defoliation timing effects on spotted knapweed seed production and viability. Rangeland Ecology \& Management 62:550-556.

BuCher, R. F. 1984. The potential cost of spotted knapweed to Montana range users. Bozeman, MT, USA: Montana State University Cooperative Extension Service. Bulletin 1316. $18 \mathrm{p}$.

DAUBenmiRE, R. 1959. A canopy-coverage method of vegetational analysis. Northwest Science 33:43-64.

DAVITT, B. B., AND J. R. Nelson. 1980. A method of preparing plant epidermal for use in fecal analysis. Pullman, WA, USA: Washington State University College of Agriculture Research Center. Circular 0628. 4 p.

Dearden, B. L., R. E. Pegau, and R. M. Hansen. 1975. Precision of microhistological estimates of ruminant food habits. Journal of Wildlife Management 39:402-407.

De Bruijn, S. L., and E. W. Bork. 2006. Biological control of Canada thistle in temperate pastures using high density rotational cattle grazing. Biological Control 36:305-315.

Duncan, C. A. 2005. Spotted knapweed, Centaurea stoebe L. ssp. micranthos (Gugler) Hayek. In: C. A. Duncan and J. K. Clark [EDs.]. Invasive Plants of Range and Wildlands and their Environmental, Economic, and Societal Impacts. Lawrence, KS, USA: Weed Science Society of America. p. 51-68.

El Aich, A., A. Moukadem, and L. R. RitTenhouse. 1989. Feeding station behavior of free-grazing sheep. Applied Animal Behaviour Science 24:259-265.

Freeman, A. S., M. L. Galyean, and J. S. Caton. 1992. Effects of supplemental protein percentage and feeding level on intake, ruminal fermentation, and digesta passage in beef steers fed prairie hay. Journal of Animal Science 70:1562-1572.

Frost, W. E., E. L. Smith, and P. R. Ogden. 1994. Utilization guidelines. Rangelands $16: 256-259$

GodDaRD, J. 1968. Food preferences of two black rhinoceros populations. East African Wildlife Journal 6:1-18.

GrifFith, D., AND J. R. LACEY. 1991. Economic evaluation of spotted knapweed (Centaurea maculosa) control using picloram. Journal of Range Management 44:43-47.

HiRSCH, S. A., AND J. A. Leitch. 1996. The impact of knapweed on Montana's economy. Fargo, ND, USA: North Dakota State University Agricultural Experiment Station. Agricultural Economics Report 355. 43 p. 
HobBs, N. T., And D. C. Bowden. 1982. Confidence intervals on food preference indices. Journal of Wildlife Management 46:505-507.

HoleCHEK, J. L., AND B. D. Gross. 1982a. Training needed for quantifying simulated diets from fragmented range plants. Journal of Range Management 35:644-647.

HolecheK, J. L., and B. D. Gross. 1982b. Evaluation of different calculation procedures for microhistological analysis. Journal of Range Management 35: 721-723.

HolecheK, J. L., and R. Valdez. 1985. Magnification and shrub stemmy material influences on fecal analysis accuracy. Journal of Range Management 38: 350-352.

KRUEGER, W. C. 1972. Evaluating animal forage preference. Journal of Range Management 25:471-475.

KueHL, R. 0. 2000. Design of experiments: statistical principles of research design and analysis. 2nd ed. Pacific Grove, CA, USA: Duxberry Press. 666 p.

LACEY, J. R., AND W. P. Volk. 1993. Forage use: a tool for planning range management. Bozeman, MT, USA: Montana State University Extension Service. Bulletin 30. 12 p.

Launchbaugh, K., and J. Hendrickson. 2001. Prescription grazing for Centaurea control on rangelands, In: L. Smith [ED.]. The First International Knapweed Symposium of the Twenty-First Century; 15-16 March 2001; Coeur d'Alene, ID, USA. Albany, CA, USA: USDA-ARS. p. 27-32.

Lee-Campbell, K. [ed.]. 1999. Best management practices for grazing Montana. Helena, MT, USA: Montana Department of Natural Resources and Conservation. $29 \mathrm{p}$.

Leslie, D. M., Jr., M. Vavra, E. E. Starkey, and R. C. Slater. 1983. Correcting for differential digestibility in microhistological analysis involving common coastal forages of the Pacific Northwest. Journal of Range Management 36:730-732.

McKinney, E. 1997. It may be utilization, but is it management? Rangelands 19:4-7.

McLean, A., And W. Willms. 1977. Cattle diets and distribution on spring-fall and summer ranges near Kamloops, British Columbia. Canadian Journal of Animal Science 57:81-92.

Miller, R. F., And W. C. Krueger. 1976. Cattle use on summer foothill rangelands in northeastern Oregon. Journal of Range Management 29:367-371.

Mueggler, W. F., AND W. L. SteWART. 1980. Grassland and shrubland habitat types of western Montana. Ogden, UT, USA: USDA Forest Service Intermountain Forest and Range Experiment Station. General Technical Report INT-66. 154 p.

Montana Weed Summit Steering Committee. 2005. The Montana weed management plan, revised. Helena, MT, USA: Montana Department of Agriculture. $88 \mathrm{p}$.

Olson, B. E., and R. T. Wallander. 2001. Sheep grazing spotted knapweed and Idaho fescue. Journal of Range Management 54:25-30.

Olson, B. E., R. T. Wallander, and J. R. Lacey. 1997. Effects of sheep grazing on a spotted knapweed-infested Idaho fescue community. Journal of Range Management 50:386-390.
Park, K. K., L. J. Krysl, B. A. McCracken, M. B. Judkins, and D. W. Holcombe. 1994. Steers grazing intermediate wheatgrass at various stages of maturity: effects on nutrient quality, forage intake, digesta kinetics, ruminal fermentation, and serum hormones and metabolites. Journal of Animal Science 72:478-486.

Ralphs, M. H., J. E. Bowns, and G. D. Manners. 1991. Utilization of larkspur by sheep. Journal of Range Management 44:619-622.

RalPhS, M. H., AND J. D. OLSEN. 1992. Prior grazing by sheep reduces waxy larkspur consumption by cattle: an observation. Journal of Range Management 45:136-139.

RoвBINS, J. 1990. Grazing knapweed using holistic resource management. In: B. F. Roche, Jr., and C. T. Roche [EDS.]. Proceedings of the Range Weeds Revisited Symposium; 24-26 January, 1989; Spokane, WA, USA. Pullman, WA, USA: Washington State University Cooperative Extension. p. 39-41.

Ruyle, G. B., AND D. D. Dwyer. 1985. Feeding stations of sheep as an indicator of diminished forage supply. Journal of Animal Science 61:349-353.

Schmutz, E. M., G. A. Holt, and C. C. Michaels. 1963. Grazed-class method of estimating forage utilization. Journal of Range Management 16:54-60.

Sheley, R. L., J. S. Jacobs, and M. L. Carpinell. 1999. Spotted knapweed. In: R. L. Sheley and J. K. Petroff [EDS.]. Biology and management of rangeland weeds. Corvallis, OR, USA: Oregon State University Press. p. 350-361.

Sparks, D. R., and J. C. MalecheK. 1968. Estimating percentage dry weight in diets using a microscopic technique. Journal of Range Management 21:264-265.

Surber, L. M. M., M. E. Rude, B. L. Roeder, T. K. Mosley, A. V. Grove, J. W. Walker, AND R. W. Kott. 2011. Percent spotted knapweed (Centaurea stoebe) in the diets of grazing sheep. Invasive Plant Science and Management 4:95-101.

Thrift, B. D., J. C. Mosley, T. K. Brewer, B. L. Roeder, B. E. Olson, and R. W. Kott. 2008. Prescribed sheep grazing to suppress spotted knapweed on foothill rangeland. Rangeland Ecology \& Management 61:18-25.

Torstenson, W. L. F., J. C. Mosley, T. K. Brewer, M. W. Tess, and J. E. Knight. 2006. Elk, mule deer, and cattle foraging relationships on foothill and mountain rangeland. Rangeland Ecology \& Management 59:80-87.

TYSeR, R. W., AND C. H. Key. 1988. Spotted knapweed in natural area fescue grasslands: an ecological assessment. Northwest Science 62:151-159.

uS Department of Agriculture-US Department of the Interior. 1996. Utilization studies and residual measurements. Denver, CO, USA: Bureau of Land Management. Interagency Technical Reference BLM/RS/ST-96/004+1730. $174 \mathrm{p}$.

USDA-NRCS. 2003. Web soil survey: Missoula County Area, Montana, Perma gravelly loam. Available at: http://websoilsurvey.nrcs.usda.gov/. Accessed 14 September 2006.

VAVRA, M., AND J. L. HolecheK. 1980. Factors influencing microhistological analysis of herbivore diets. Journal of Range Management 33:371-347.

Watson, A. K., and A. J. Renney. 1974. The biology of Canadian weeds. Centaurea diffusa and C. maculosa. Canadian Journal of Plant Science 54:687-701. 